\title{
Effect of Application of Jatropha Curcas Leaves, Glricidia Sepium Leaves and NPK Fertilizer on Maize Growth in Ibadan, Oyo State.
}

\author{
Adebisi, A.A, Geply, O.A, Adiji, A.O and Oriire, L.T \\ Forestry Research Institute Of Nigeria P.M.B. 5054 Jericho, Ibadan \\ DOI: 10.29322/IJSRP.11.07.2021.p11542 \\ http://dx.doi.org/10.29322/IJSRP.11.07.2021.p11542
}

\begin{abstract}
The study was carried at Teaching and Research farm of Forestry Research Institute of Nigeria Ibadan to investigate the effect of application of Jatropha curcas leaves, Glricidia sepium leaves and NPK fertilizer on maize growth.

The experiment consisted of seven treatments which include Jatropha curcas leaves, Glricidia sepium leaves, fertilizer, fertilizer/Jatropha sepium leaves, fertilizer/Gliricidia sepium leaves, fertilizer/Jatropha leaves/Glricida sepium leaves and no application of treatment serve as a control using maize a test crop. The treatment were replicated three (3) times on twenty one (21) micro plots $(5 \mathrm{mX} 5 \mathrm{~m})$ in dimension. The growth parameters measured included: plant height, collar diamater and plant dry weight at 4, 6 and 8weeks after application of treatments. Data generated were analyzed using ANOVA procedures for CRD. Therefore, the results obtained showed that there is a significant difference in plot treated with fertilizer/Jatropha curcas leaves/Glricidia sepium leaves interms of growth height, collar diameter,dry weight of leaves,stem dry weight and root dry weight compared to other six treatments. It is recommended that combined of organic and inorganic fertilizer is required for sustainability of soil productivity under intensive cultivation.
\end{abstract}

Index Terms- Jatropha curcas, Gliricidia sepium, maize and fertilizer application

\section{INTRODUCTION}

$\mathrm{M}$ ore scientific and innovative advancements in agriculture shows strong potentials to help increase farmers yield. It is no secret that the words demand for food especially grains is accelerating as popoulation and per capital consumption increases at an unprecedented rate. The quest to grow food to meet that demand and feed the world population will continue to be one of the most important issues of our time. Globally, inorder to meet the food and nutrition needs of more than 9billion people by 2050, farmers will have to grow as much food as they have grown in the last 100years combined(Sagiinga and Woomer2009). Moreover due to shortage of land and increasing population pressure, shortage fallow periods like agroforestry are being adopted by farmers, reducing the efficiency and sustainability of this practice(Oke, 2002).

In Nigeria decline in soil fertility is a severe problem facing small holder farming. It is necessesity to provide alternative sources of nutrients that will serves as a substitute to inorganic fertilizer(Adebisi, etal 2019). The high cost of scarcity and low efficiency of fertilizers make them unprofitable for farmers. Also without adequate supply of organic matter, continuous use of NPK fertilizers leads to soil acidification, nutrient in balances and degradation in soil physical quality (Fasina, 2013).

The approach focus on maintaining or enhancing soil productivity through a balance use of mineral fertilizers combined with organic sources including green manuring, mulch, uses of legumes for biological fixation and use of crop residues and domestic wastes. The study therefore investigates effect of application of Jatropha leaves, Gliricidia sepium leaves and NPK fertilizer in Ibadan with a view to determine the effect of organic and inorganic fertilizer treatment for maize crop performances.

\section{MATERIALS AND METHODS}

This study was carried out at the Teaching and Research farm of the, Forestry Research Institute of Nigeria Ibadan. The geographical location of experimental site is located at Longitude $07^{0} 23^{1} 18^{11}$ to $08^{0} 23^{1} 43^{11} \mathrm{~N}$ and Latitude $03^{0} 51^{1} 20^{11}$ to $03^{0} 23^{1}$ $43^{11} \mathrm{E}$. The climate of the area is tropical with annual rainfall ranging from $1400-1500 \mathrm{~mm}$ while the average temperature is about $32^{\circ} \mathrm{c}$ and Relative humidity is about $65 \%$. The soil texture is fairly drained clayey loamy soil rich with good water retention and permeability.

A landed area of $525 \mathrm{~m}^{2}(15 \mathrm{~m} \times 35 \mathrm{~m})$ was marked out and cleared at the experimental plot of Forestry Research Institute of Nigeria, Ibadan for Agroforestry research. The area was demarcated into twenty one (21) microplots $(5 \mathrm{mx} 5 \mathrm{~m})$ with buffer zone of $1 \mathrm{mx} 1 \mathrm{~m}$ between plots. Three of the microplots were selected randomly for fertilizer/Jatropha curcas leaves/Glricidia sepium leaves, three of the microplots were selected randomly for Jatropha curcas leaves application, three of the microplots were selected randomly for Gliricidia sepium leaves, three microplots were also selected for fertilizer application, three microplots for fertilizer/Jatropha curcas leaves, another three microplots for fertilizer /Glricidia sepium leaves and three with no application of treatments was serve as a control. Maize seeds were planted sown in all plots at a spacing of $(90 \mathrm{~cm} \times 30 \mathrm{~cm})$ within and between rows. The Jatropha curcas leaves and Glricidia sepium leaves was collected from the plantation at the institute arboretum. Also the Jatropha curcas leaves and Glricidia sepium leaves were analyzed 
at International Institute of Tropical Agriculture (IITA), Ibadan for total Nitrogen $(\mathrm{N})$, total Potassium $(\mathrm{P})$ and total Phosphorus $(\mathrm{K})$. Prior to seed germination, the whole plots were weeded manually in order to suppress the weed competition with the maize crop growth. The rate at which the treatment was applied on the plots are:- Jatropha curcas leaves $=5$ tonnes $/$ ha $(80 \mathrm{~kg} / \mathrm{plot})$, Glricidia sepium leaves $=5$ tonnes $/$ ha $(80 \mathrm{~kg} / \mathrm{plot})$, Fertilizer $=40 \mathrm{~kg} / \mathrm{ha}$ $(640 \mathrm{~g} / \mathrm{plot})$, Fertilizer/Jatropha curcas leaves $=320 \mathrm{~g}+40 \mathrm{~kg}$, Fertilizer/Glricidia sepium leaves $=320 \mathrm{~g}+40 \mathrm{~kg}$, Fertilizer/ Jatropha curcas leaves / Glricidia sepium leaves = $213+27 \mathrm{~kg}+27 \mathrm{~kg}$, Control - No application of treatment serves as a control.

During the growth stage of the Maize growth parameter such as plant height, collar diameter and dry matter yield was done. The measurement of plant height and collar diameter was done at 4, 6 and 8 weeks after treatment of application. One plant with collar diameter closet to the mean was selected after each measurement was uprooted for dry matter weight determination. The plants were separated into roots, stems and leaves placed in the envelopes and were oven dried for 24 hours at $65^{\circ}$ to a constant weight. All data collected were subjected to one-way analysis of variance (ANOVA) test at 5\% level of significance. Where the follow up test was carried out using Fisher's least significant difference (LSD) to identify means were significantly different.

\section{RESUlTS AND DISCUSSION}

The results of variance (ANOVA) tables obtained in this research work are shown in appendices. The results are presented under the following headings: effects of application of Jatropha curcas leaves, Glricidia sepium leaves and NPK fertilizer on height growth of maize, effects of application of Jatropha curcas leaves, Glricidia sepium leaves and NPK fertilizer on collar diameter of maize, effect of application of Jatropha curcas leaves, Glricidia sepium leaves and NPK fertilizer on leaves dry weight of maize, effects of application of Jatropha curcas leaves, Glricidia sepium leaves and NPK fertilizer on stem dry weight of maize, effects of application of Jatropha curcas leaves, Glricidia sepium leaves and NPK fertilizer on root dry weight of maize crop.

Effect Of Application Of Jatropha Curcas Leaves, Glricidia Sepium Leaves And NPK Fertilizer On Height Growth Of Maize.

The plant height measured at different time after application of treatments(4,6 and 8 weeks) in Table1 at appendice below shows maize plant height as influenced by Jatropha curcas leaves, Glricidia sepium leaves,NPK fertilizer application, fertilizer/Jatropha curcas leaves application,fertilizer/Glricidia sepium leaves,fertilizer/ Jatropha sepium leaves/ Glricidia sepium and no application of fertilizer and mulching. Statistical analysis of data shows that these treatments had a significantly different effect on maize height. The highest mean plant height was recorded for fertilizer/ Jatropha sepium leaves/ Glricidia sepium leaves and the least mean plant height was recorded for no application of fertilizer and mulching. The analysis of variances (ANOVA) tables for 6 and 8 weeks after application of treatment shows that there was significant difference in the height of the maize crop grown under different treatments while there was no significant difference in the height of the maize crop planted under the same treatments in 4 weeks after the application of treatment. From follow up analysis, it shows that there was no height growth difference in all the application treatment except the treatment with no application which serves as a control that had the least.

\section{Effect Of Application Of Jatropha Curcas Leaves, Glricidia Sepium Leaves And NPK Fertilizer On Collar Diameter Of Maize}

Table 2 at appendice below shows that there was significant different in collar diameter of maize crop under the different treatments at 4, 6 and 8 weeks after application of treatments. From the follow up analysis, there was no significant difference in the growth of collar diameter of maize planted with treatment of fertilizer, Jatropha sepium leaves and Glricidia sepium leaves and no application of treatment which serves as a control. Comparing the mean values, there is rapid growth of collar diameter on fertilizer/Jatropha curcas leaves/Glricidia sepium leaves, fertilizer/Jatropha curcas leaves and fertilizer/Glricidia sepium leaves.

\section{Effects Of Application Of Jatropha Curcas Leaves, Glricidia Sepium Leaves And NPK Fertilizer On Leaves Dry Weight Of Maize}

Table 3 at appendice below shows that there was no significant difference on the leaves dry weight, fertilizer/Jatropha sepium leaves,fertilizer/ Glricidia sepium leaves at 4 weeks after application of treatment. In 6 weeks after application of treatment, there is no significant difference in biomass of the maize crop subjected to fertilizer, fertilizer/Jatropha sepium leaves, fertilizer/ Glricidia sepium leaves mulching compare with the fertilizer/Jatropha curcas leaves/Glricidia sepium leaves that had the highest records while the control had the least records. While in 8 weeks after application of treatment, there is no significant difference in the maize leaves dry under fertilizer/Jatropha sepium leaves, Glricidia sepium leaves treatment. While there is highest records in fertilizer/Jatropha curcas leaves,Glricidia sepium leaves and control with no treatment had the least records.

\section{Effect Of Application Of Jatropha Curcas Leaves, Glricidia Sepium Leaves And NPK Frtilizer On Stem Dry Weight Of Maize}

Table 4 at appendice below shows that there was significant difference on growth of stems of the maize crop among the treatments. In 4 and 6 weeks after application of fertilizer, there was no significant difference in the growth of stems among fertilizer, Jatropha curcas leaves, Glricidia sepium leaves mulching compare to fertilizer/Jatropha curcas leaves, Fertilizer/Glricidia sepium leaves. In 8 weeks after application, there was significant difference in the growth of stems among all the treatments except the no appliction of treatment that had the least records. Using the mean values, there was more growth of stems in fertilizer/Jatropha curcas leaves/Glricidia sepium leaves treatment followed by application of fertilizer/Jatropha curcas leaves and fertilizer/Glricidia sepium leaves.

Effect of application of Jatropha curcas leaves, Glricidia sepium leaves and NPK fertilizer on root dry weight of maize crop

This publication is licensed under Creative Commons Attribution CC BY

http://dx.doi.org/10.29322/IJSRP.11.07.2021.p11542

WWW.ijsrp.org 
Table 5 at the appendice below shows that there was slight significant difference in the root of the maize crop planted under the treatments. From follow up analysis, in 4 weeks, there was significant difference in the root growth among the treatments. In 6 and 8 weeks, there was no difference in the growth of stems in maize planted under fertilizer, fertilizer/Jatropha curcas leaves, fertilizer/Glricidia sepium leaves and no application of treatment compare to fertilizer/ Jatropha curcas leaves/ Glricidia sepium leaves.

\section{DISCUSSION}

From the results above, the growth of maize crop planted in fertilizer/Jatropha curcas leaves,fertilizer/Glricidia sepium leaves plots and Jatropha curcas leaves,fertilizer/Glricidia sepium leaves only are very high. In the sub tropics mulching give better yield and also improve soil structure and water holding capacity. It also checks soil and also suppressed weeds. The decomposition of these organic materials from the trees does not only supply nutrient in the soil but also increase plant availability of nutrients in the soil by processing such supplied energy source to organisms thereby enhancing nutrient cycle through soil organisms, reducing erosion evaporation, lower soil temperature and stimulating root growth. Application of organic materials at the beginning of the cropping period, nitrogen contents would be release and also when the NPK fertilizer was supplemented to the mulching of Jatropha curcas and Glricidia sepium it therefore increased the nutrient content of the soil and balance the nutrient available in the soil which leads to increase in the growth of the maize cultivated.

However, this study showed that the fertilizer with combination of Jatropha sepium curcas and Glricidia sepium leaves mulch gave the best growth in terms of plant height at 4WAP, 6WAP and 8WAP finally gave better crop growth. In addition, organic matter is a rich sources of plant nutrients especially N,P and S. These attributes probably make the plants treated with organic fertilizer either singly of fortified with microdose of NPK fertilizer results in greater height and collar diameter growth compared with NPK fertilizer treated plants (Ojeniyi,2012).

\section{CONCLUSION}

With respect to the various researches during the course of this study that improving soil quality and crop production on farms is a major issue for agricultural research. The project has contributed additional knowledge about some of the process governing nutrient cycling in farmland these process helps when recommendation for future management. Supplementation of fertilizer with mulching results in yield increase compare to those achieved with application of inorganic, mulch and without any application only, this is nutrient resources management option. There is need to develop and improve this innovation that the supplement of nitrogen, phosphorus and potassium with mulching is highly desirable.

Finally, the best grown interms of growth or height and yield matter were recorded for fertilizer/Jatropha curcas leaves/Glricidia sepium leaves for all the weeks after application the treatment. A follow up test (LSD) result showed that the treatment is significantly different in comparison to other treatments.

\section{REFERENCES}

[1] Adebisi, A. A., Oke, D. O, Oriire, L. T. and Adegoke, I. A. (2013): Effects of Supplemental Application of Phosphorus Fertilizer on Maize Growth in Gliricidia sepium-Maize Alley Cropping System. International Journal of Applied Research and Technology. 2(3): $59-64$

[2] Adebisi, A.A, Oke, D.O and Geply, O.A. (2019): Influence of application of leaves and seedcake of Jatropha curcas and NPK fertilizer on Maize Growth. International Journal of Applied Research and Technology. Vol 8(6):pp1419.

[3] Fasina, A.S; (2013): Can these soils sustain. 37th Inaugural Lecture Ekiti State University Ado Ekiti, 76pp.

[4] Ojeniyi, S.O; (2012): Tropical soil management and agriculture production systems in African. International Institute of Tropical Agriculture (IITA) Ibadan, Nigeria 66pp.

[5] Oke, D.O; (2002): Planted tree fallow; A sustainable option for improved rural livelihood. In J.E Abu, P.I, Oni and L. Popoola (Eds), Proceeding of 28th Annual Conference of the Forestry Association of Nigeria, pp 4-8 November, Akure, Nigeria.

[6] Oyun, M.B; (2008): Evaluation of growth and Yield of Maize (Zea mays L) as varying pruning Regime under Glricidia-maize Alley cropping in Akure, Nigeria. Forest and Forest Products Journal, 1:58-62.

[7] Saginga, N and Woomer, P.L (Eds), (2009): Integrated soil fertility management in Africa Principles, Practices and development process. Tropical soil Biology and fertility. Institute of International centre for Tropical Agriculture, Nairobi.263pp.

\section{AUTHORS}

First Author - Author name, qualifications, associated institute (if any) and email address.

Second Author - Author name, qualifications, associated institute (if any) and email address.

Third Author - Author name, qualifications, associated institute (if any) and email address.

Correspondence Author - Author name, email address, alternate email address (if any), contact number.

Table1: Nutrient content (\%) on dry matter of Glricidia leave and Jatropha leaves.

\begin{tabular}{llll} 
Nutrients & Nitrogen & Phosphorus & Potassium \\
\hline Jatropha curcas leaves & 3.40 & 0.39 & 0.68 \\
Glricidia sepium leaves & 3.54 & 0.23 & 0.67
\end{tabular}


Table 2: Effect of application Jatropha leaves, Gliricidia leaves, and NPK fertilizer height growth of maize Weeks

$\mathbf{J L}$

GL

F

F/GL

F/JL

F/JL/GL

C

$\begin{array}{cccccccc}4 & 0.48^{\mathrm{a}} & 0.74^{\mathrm{b}} & 0.57^{\mathrm{b}} & 0.42^{\mathrm{a}} & 0.48^{\mathrm{a}} & 0.64^{\mathrm{b}} & 0.32^{\mathrm{a}} \\ 6 & 0.95^{\mathrm{a}} & 1.22^{\mathrm{b}} & 1.82^{\mathrm{c}} & 1.11^{\mathrm{b}} & 1.31^{\mathrm{a}} & 1.50^{\mathrm{a}} & 0.75^{\mathrm{a}} \\ 8 & 1.15^{\mathrm{a}} & 1.70^{\mathrm{a}} & 1.98^{\mathrm{b}} & 1.82^{\mathrm{b}} & 1.79^{\mathrm{b}} & 2.12^{\mathrm{c}} & 1.08^{\mathrm{a}}\end{array}$

Means on the same row having the same superscript are not significantly difference at $\mathrm{P} \geq$

Table3: Effect of application Jatropha leaves, Gliricidia leaves, and NPK fertilizer collar diameter of maize

\begin{tabular}{|c|c|c|c|c|c|c|c|c|}
\hline Weeks & $\mathbf{J L}$ & GL & $\mathbf{F}$ & F/GL & F/JL & \multicolumn{2}{|c|}{ F/JL/GL } & $\mathbf{C}$ \\
\hline 4 & $7.18^{\mathrm{a}}$ & $9.76^{\mathrm{a}}$ & $9.56^{\mathrm{a}}$ & $13.11^{\mathrm{b}}$ & $12.48^{\mathrm{b}}$ & $15.01^{\mathrm{c}}$ & $7.78^{c}$ & \\
\hline 6 & $11.80^{\mathrm{a}}$ & $13.07^{\mathrm{b}}$ & $15.05^{\mathrm{bc}}$ & $18.68^{c}$ & $16.81^{\mathrm{c}}$ & $19.73^{c}$ & $10.41^{\mathrm{a}}$ & \\
\hline 8 & $12.90^{\mathrm{a}}$ & $13.45^{\mathrm{a}}$ & $15.83^{\mathrm{b}}$ & $20.01^{\mathrm{c}}$ & $17.95^{\mathrm{c}}$ & $22.01^{\mathrm{c}}$ & $11.99^{\mathrm{a}}$ & \\
\hline
\end{tabular}

Means on the same row having the same superscript are not significantly difference at $\mathrm{P} \geq$

Table4: Effect of application Jatropha leaves, Gliricidia leaves, and NPK fertilizer leaves dry weight of maize

\begin{tabular}{|c|c|c|c|c|c|c|c|c|}
\hline Weeks & $\mathbf{J L}$ & GL & & & F/GL & F/JL & \multicolumn{2}{|c|}{ F/JL/GL } \\
\hline & 4 & $3.26^{\mathrm{a}}$ & $4.91^{\mathrm{a}}$ & $7.26^{\mathrm{a}}$ & $7.31^{\mathrm{a}}$ & $6.84^{\mathrm{a}}$ & $15.33^{\mathrm{b}}$ & $1.82^{\mathrm{a}}$ \\
\hline & 6 & $19.57^{\mathrm{c}}$ & $6.75^{\mathrm{a}}$ & $10.01^{\mathrm{b}}$ & $14.01^{\mathrm{bc}}$ & $19.57^{\mathrm{c}}$ & $21.65^{\mathrm{c}}$ & $8.65^{\mathrm{a}}$ \\
\hline & 8 & 21.01 & $9.68^{\mathrm{a}}$ & $10.52^{\mathrm{b}}$ & $20.11^{\mathrm{c}}$ & $21.99^{c}$ & $22.55^{\mathrm{c}}$ & $8.30^{\mathrm{a}}$ \\
\hline
\end{tabular}

Means on the same row having the same superscript are not significantly difference at $\mathrm{P} \geq$

Table5: Effect of application Jatropha leaves, Gliricidia leaves, and NPK fertilizer stem dry weight of maize

\begin{tabular}{|c|c|c|c|c|c|c|c|c|}
\hline Weeks & JL & GI & & & F/GL & F/JL & \multicolumn{2}{|c|}{ F/JL/GL } \\
\hline & 4 & $8.14^{\mathrm{a}}$ & $11.21^{\mathrm{b}}$ & $9.96^{\mathrm{a}}$ & $12.54^{\mathrm{b}}$ & $12.64^{\mathrm{b}}$ & $12.96^{\mathrm{b}}$ & $3.61^{\mathrm{a}}$ \\
\hline & 6 & $17.55^{\mathrm{b}}$ & $28.11^{\mathrm{c}}$ & $27.10^{c}$ & $18.69^{b}$ & $17.89^{\mathrm{b}}$ & $25.99^{\mathrm{c}}$ & $5.52^{\mathrm{a}}$ \\
\hline & 8 & $20.01^{\mathrm{a}}$ & $29.55^{\mathrm{b}}$ & $32.99^{c}$ & $47.92^{\mathrm{d}}$ & $45.78^{\mathrm{d}}$ & $59.01^{\mathrm{d}}$ & $15.28^{\mathrm{a}}$ \\
\hline
\end{tabular}

Means on the same row having the same superscript are not significantly difference at $\mathrm{P} \geq$ 
Table6: Effect of application Jatropha leaves, Gliricidia leaves, and NPK fertilizer root dry weight of maize

\begin{tabular}{|c|c|c|c|c|c|c|c|c|}
\hline Weeks & JL & GI & & & F/GL & F/JL & \multicolumn{2}{|c|}{ F/JL/GL } \\
\hline & 4 & $0.44^{\mathrm{a}}$ & $0.73^{\mathrm{a}}$ & $0.47^{\mathrm{a}}$ & $1.03^{\mathrm{b}}$ & $1.11^{\mathrm{b}}$ & $1.27^{\mathrm{b}}$ & $0.22^{\mathrm{a}}$ \\
\hline & 6 & $1.21^{\mathrm{b}}$ & $0.77^{\mathrm{a}}$ & $1.83^{\mathrm{b}}$ & $2.14^{\mathrm{c}}$ & $2.20^{\mathrm{c}}$ & $4.98^{\mathrm{d}}$ & $0.75^{\mathrm{a}}$ \\
\hline & 8 & $1.01^{\mathrm{a}}$ & $1.20^{\mathrm{ab}}$ & $2.51^{\mathrm{b}}$ & $2.86^{\mathrm{c}}$ & $2.78^{c}$ & $5.45^{\mathrm{d}}$ & $0.77^{\mathrm{a}}$ \\
\hline
\end{tabular}

Means on the same row having the same superscript are not significantly difference at $\mathrm{P} \geq$

Figure 1: Experimental plot

\begin{tabular}{|c|c|c|c|c|c|c|}
\hline T1 & T3 & $\mathbf{T} 4$ & T5 & T6 & T7 & \\
\hline JCL1 & GSL1 & F1 & F/JCL1 & F/GSL1 & F/JCL/GSL1 & C1 \\
\hline $\mathbf{C 2}$ & F/JCL/GSL2 & F/GSL2 & F2 & GSL2 & F/JCL2 & JCL2 \\
\hline F/GSL & F3 & F/JCL3 & JCL3 & $\mathrm{C3}$ & F/JCL/GSL3 & GSL3 \\
\hline
\end{tabular}

$\mathbf{J L}=$ Jatropha curcas leaves application, $\mathbf{G S L}=$ Glricidia sepium leaves application, $\mathbf{F}=$ fertilizer application, $\mathbf{F} / \mathbf{J C L}=$ fertilizer $/$ Jatropha curcas application, $\mathbf{F} / \mathbf{J C L} / \mathbf{G S L}=$ fertilizer/Jatropha curcas leaves/Glricidia sepium leaves application, $\mathbf{C}=$ Control no applicaton of treaments. 